Jurnal InFestasi

Vol. 11, No.2, Desember 2015

Hal. 151 - 170

\title{
DETERMINAN KESUKSESAN APLIKASI SIA KOMDANAS PADA SATUAN KERJA DI KOORDINATOR WILAYAH PENGADILAN TINGGI MATARAM
}

\author{
Lalu Afghan Muharor ${ }^{1}$ \\ Busaini 2 \\ Nur Fitriah 2 \\ ${ }^{1}$ Sub Bagian Keuangan Pengadilan Tinggi Mataram \\ 2 Fakultas Ekonomi dan Bisnis, Universitas Mataram \\ laluafghan@gmail.com
}

\begin{abstract}
The objective of this study is to examine the positive effect of information system quality, information quality and service quality on user satisfaction and use of system, the effect of use of system to user satisfaction, the effect of user satisfaction on use of system, the effect of use on net benefits and the effect of user satisfaction on net benefits. Data used in this study is primary data based on questionnaires distributed to the users of komdanas who work at work unit under the regional coordinators Pengadilan Tinggi Mataram. In this study, I use smart partial least square to examine 102 returned questionnaires.

The results of this study show that information quality statistically positive affects the use of system but statistically negative affects the user satisfaction, system quality statistically positive affects the use of system and user satisfaction, service quality statistically positive affects the user satisfaction but statistically negative affects the use of system, use of system statistically positive affects the user satisfaction, user satisfaction statistically positive affects the use of system, use of system statistically did not affect the net benefits and user satisfaction statistically positive affects the net benefits.
\end{abstract}

Key Words: information quality, system quality, service quality, use of system, user satisfaction, net benefits.

\begin{abstract}
Abstrak
Tujuan dari penelitian ini adalah untuk menguji pengaruh positif kualitas informasi, kualitas sistem dan kualitas pelayanan terhadap penggunaan dan kepuasan pengguna, penggunaan terhadap kepuasan pengguna, kepuasan pengguna terhadap penggunaan, penggunaan terhadap manfaat bersih dan kepuasan pengguna terhadap manfaat bersih. Data yang digunakan dalam penelitian ini adalah data primer yang didapat dengan menyebarkan kuesioner terhadap pengguna komdanas di seluruh satuan kerja dibawah korwil Pengadilan Tinggi Mataram. Alat analisis yang digunakan untuk menguji 102 kuesioner dalam penelitian ini adalah Smart PLS.

Hasil penelitian menunjukkan bahwa variabel kualitas informasi berpengaruh positif terhadap penggunaan tetapi berpengaruh negatif terhadap kepuasan pengguna, kualitas sistem berpengaruh positif terhadap penggunaan dan kepuasan pengguna, kualitas pelayanan berpengaruh positif terhadap kepuasan pengguna tetapi berpengaruh negatif terhadap penggunaan, penggunaan tidak berpengaruh terhadap manfaat bersih dan kepuasan pengguna berpengaruh positif terhadap manfaat bersih.

Kata Kunci : kualitas informasi, kualitas sistem, kualitas pelayanan, penggunaan, kepuasan pengguna, manfaat bersih.
\end{abstract}




\section{PENDAHULUAN}

Kemajuan teknologi informasi saat ini menjadikan sistem informasi akuntansi berkembang menjadi sistem informasi akuntansi yang berbasis komputer. Sistem Informasi Akuntansi yang terkomputerisasi memungkinkan pengguna laporan keuangan dapat melihat laporan keuangan setiap saat dengan lebih cepat dan akurat. Penyajian informasi keuangan dan nonkeuangan dapat dilakukan dengan lebih mudah dengan adanya dukungan paket program sistem informasi (Istianingsih dan Utami, 2009).

Pemerintah selaku pengelola dana masyarakat harus mampu menyediakan informasi keuangan yang diperlukan secara akurat, relevan, tepat waktu, dan dapat dipercaya. Pemerintah dituntut memiliki sistem informasi yang andal. Jika sistem informasi akuntansi yang dimiliki masih lemah, kualitas informasi yang dihasilkan dari sistem tersebut juga kurang andal (Wahyundaru 2001 dalam Latifah dan Sabeni 2007).

Sistem informasi adalah suatu sistem yang berkaitan dengan pengumpulan, penyimpanan, dan pemrosesan data, baik yang dilakukan secara manual maupun dengan bantuan komputer untuk menghasilkan informasi yang berguna dalam pengambilan keputusan (Mulyono 2009). Salah satu bentuk dari sistem informasi yang spesifik adalah sistem informasi akuntansi komunikasi data nasional (Komdanas) yang merupakan penerapan sistem di dalam organisasi pemerintahan untuk mendukung informasi yang dibutuhkan oleh semua tingkatan manajemen dalam rangka mengambil keputusan.Sistem aplikasi tersebut dapat digunakan sebagai pengolahan data pengelolaan keuangan di lingkungan Mahkamah Agung RI.

Meningkatnya kebutuhan akan informasi yang tepat, akurat dan handal sering menyebabkan para pengguna software akuntansi harus bekerja lebih ekstra. Masalah yang biasanya terjadi dalam penggunaan paket software akuntansi adalah tidak compatible-nya sistem dengan proses bisnis dan informasi yang diperlukan organisasi
(Janson dan Subramanian, 1996; Lucas, Walton, dan Ginzberg, 1998 dalam Istianingsih dan Wijanto 2008). Ketidaksesuaian antara software aplikasi dengan proses pengolahan data dapat menimbulkan masalah signifikan bagi pengguna seperti menurunnya tingkat kepuasan peengguna yang akan mengakibatkan penurunan kinerja, sehingga informasi yang dihasilkan tidak sesuai dengan kebutuhan.

Penelitian ini menguji pengaruh kualitas sistem informasi, kualitas informasi, dan kualitas pelayanan terhadap penggunaan dan kepuasan pengguna serta manfaat dari software akuntansi komunikasi data nasional (Komdanas) pada Satuan Kerja (satker) di lingkup Koordinator Wilayah (Korwil) Pengadilan Tinggi Mataram dengan mengacu pada penelitian yang dilakukan oleh Istianingsih dan Wijanto (2008). Namun perbedaan penelitian ini dengan penelitian yang dilakukan oleh Istianingsih dan Wijanto (2008) adalah penambahan variabel kualitas pelayanan dan manfaat bersih sebagai bagian dari kesuksesan model sistem informasi DeLone dan McLean (2003).

Komunikasi data nasional (Komdanas) merupakan sebuah sistem informasi akuntansi yang berfungsi utama sebagai media penyimpanan dan database sentral berisi data-data aset, keuangan, dan remunerasi di lingkungan peradilan (MA 2011). Komdanas pada awalnya diharapkan berperan dalam proses kompilasi, verifikasi, akurasi data aset, keuangan, dan remunerasi, serta penyusunan laporan aset, keuangan, dan dokumen pengajuan remunerasi yang selama ini tidak efisien dan banyak memerlukan waktu. Aplikasi komdanas merupakan aplikasi berbasis web terpadu, sehingga tidak perlu di-install di setiap satuan kerja. Setiap satuan kerja hanya perlu mempunyai akun pengguna dan password untuk bisa mengakses aplikasi tersebut.Aplikasi ini terus dikembangkan dan disempurnakan. Disamping tetap menjamin hasil data laporan yang akurat dan tepat, dapat pula diakses secara cepat.Aplikasi ini juga fleksibel terhadap perubahan yang diinginkan apabila terjadi perubahan 
bentuk laporan, baik karena aturan maupun kebijakan (MA 2014).

Pengembangan dan penggunaan aplikasi Komdanas secara nasional sangat didukung penuh oleh pimpinan Mahkamah Agung Tahun 2014, Sekretaris Mahkamah Agung mengeluarkan surat Nomor: 2461/SEK/KU.01/9/2014 tanggal 17 September 2014 tentang kewajiban satuan kerja untuk menggunakan aplikasi komdanas dalam pengajuan tunjangan khusus kinerja. Dalam perkembangannya, aplikasi komdanas dikembangkan untuk memfasilitasi kerjasama antara Mahkamah Agung dan BPK dalam pelaksanaan e-audit. Dalam pelaksanaannya, seluruh data aset, keuangan, ringkasan kontrak, data absensi pegawai, dan semua data lainnya yang berhubungan dengan pelaksanaan anggaran dikirim dan disimpan oleh satuan kerja melalui aplikasi komdanas (MA 2014).

Penelitian ini menggunakan model kesuksesan DeLone dan McLean (2003) dengan melakukan pengujian sampai pada manfaat kepada organisasi untuk meneliti fenomena keberhasilan implementasi komdanas di lingkungan Koordinator Wilayah Pengadilan Tinggi Mataram dalam peningkatan produktifitas dan efektifitas satuan kerja pengadilan dengan mempercepat penyusunan laporan keuangan dan juga penerimaan remunerasi, seperti yang dituturkan oleh Panitera/Sekretaris Pengadilan Tinggi Mataram.

Secara lebih rinci berdasarkan latar belakang yang ada, rumusan masalah penelitian dituliskan dalam pertanyaan penelitian dengan mendasarkan pada pengukuran yang digunakan dalam model DeLone dan McLean (2003) yaitu apakah kualitas informasi, kualitas sistem dan kualitas pelayanan berpengaruh positif terhadap penggunaan dan kepuasan pengguna, apakah penggunaan dan kepuasan pengguna saling berpengaruh positif serta apakah penggunaan dan kepuasan pengguna berpengaruh positif terhadap manfaat bersih.

Model Kesuksesan DeLone dan McLean DeLone and McLean Information Success Model atau Model Kesuksesan Sistem Informasi DeLone dan McLean merupakan pengembangan dari penelitian-penelitian sebelumnya, diantaranya penelitian oleh Shannon \& Weaver (1949) dan Mason (1978) dalam Jogiyanto (2007) serta penelitianpenelitian sebelumnya. Model kesuksesan ini didasarkan pada proses dan hubungan kausal dari enam dimensi pengukur yaitu kualitas sistem (system quality); kualitas informasi (information quality); penggunaan(use); kepuasan pengguna (user satisfaction); dampak individual (individual impact) dan dampak organisasional (organizational impact).

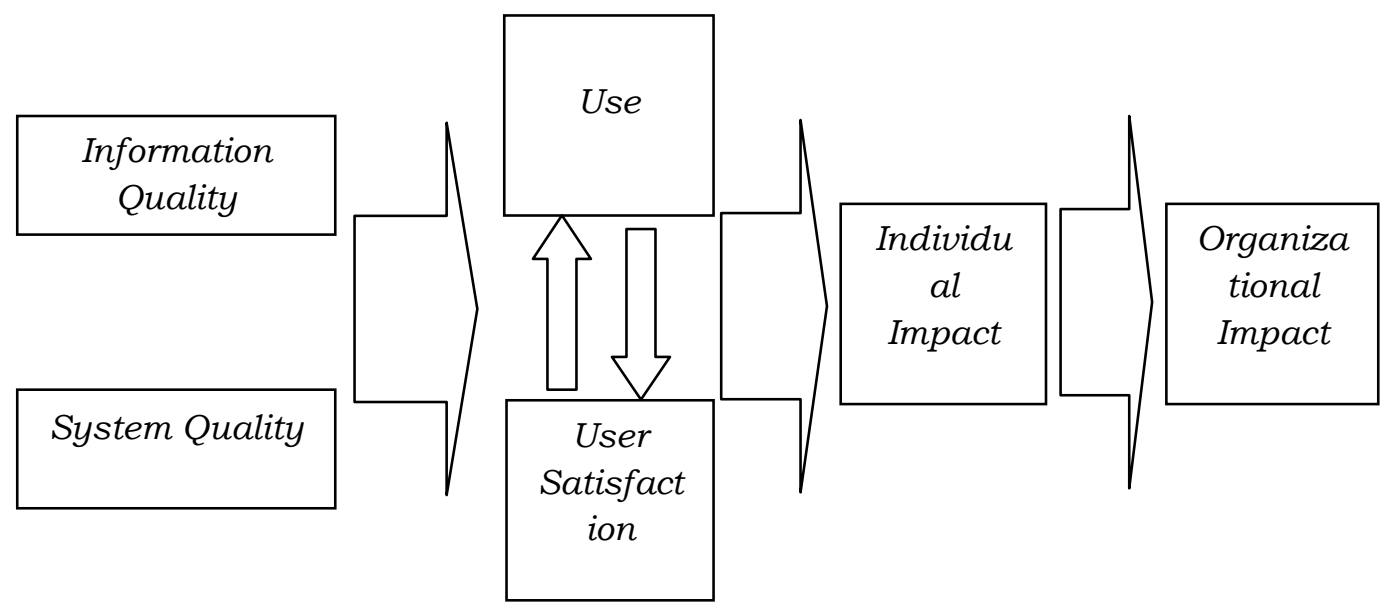

Gambar 1. Model Kesuksesan Sistem Informasi DeLone dan McLean Sumber: DeLone dan McLean 1992)

Semakin berkembangnya penelitian dibidang implementasi sistem informasi, menyebabkan banyaknya kritik dan saran untuk model yang dikembangkan 
oleh DeLone dan McLean di tahun 1992. Maka untuk menjawab dan merespon dari banyaknya kritik dan saran yang diajukan untuk model ini, pada tahun 2003 model ini mengalami perubahan. Beberapa elemen yang ditambah ataupun yang dirubah adalah sebagai berikut (1) Memasukkan variabel kualitas pelayanan (service quality) sebagai tambahan dari dimensi-dimensi kualitas yang sudah ada, yaitu kualitas sistem dan kualitas informasi, (2) Merubah dan menggabungkan variabel-variabel dampak individual dan organisasional menjadi net benefits yang tujuannya adalah untuk menjaga model tetap sederhana, (3) Menambah dimensi intensitas penggunaan sebagai alternatif dari dimensi penggunaan (use). (4) Penggunaan dan kepuasan pengguna sangat erat berhubungan. Penggunaan harus mendahului kepuasan pengguna sebagai suatu proses, tetapi pengalaman yang positif karena menggunakan sistem akan mengakibatkan kepuasan pengguna yang lebih tinggi sebagai bentuk hubungan kausal. Secara sama, peningkatan kepuasan pengguna akan mengakibatkan peningkatan intensitas menggunakan sistem dan kemudian akan menggunakan. (5) Jika net benefits bernilai positif akan menguatkan intensitas penggunaan untuk memakai sistem, dan menguatkan kepuasan pengguna. Bentuk hubungan seperti ini masih valid walaupun nilai dari net benefits tersebut menjadi negatif.

Dari analisis diatas, maka model yang diperbaharui pada tahun 2003 akan terlihat seperti gambar dibawah ini

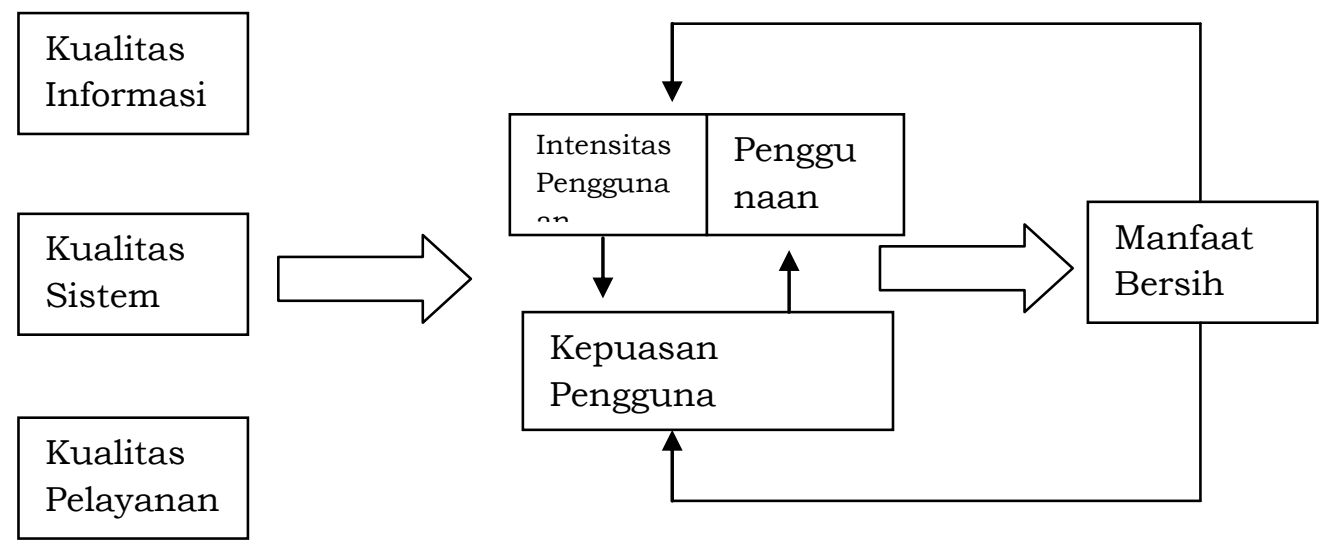

Gambar 2. Model Kesuksesan Sistem Informasi DeLone dan McLean

\section{Sistem Informasi Akuntansi}

Akuntansi merupakan bahasa bisnis dimana setiap perusahaan menerapkannya sebagai alat komunikasi baik dalam manajemennya maupun keluar seperti investor dan kreditur guna mencapai tujuan yang ingin dicapainya. Secara klasik, akuntansi merupakan proses pencatatan (recording), pengelompokkan (classifying), perangkuman (summarizing), dan pelaporan (reporting) dari kegiatan transaksi perusahaan. Tujuan akhir dari kegiatan akuntansi adalah penerbitan laporan keuangan. Laporan keuangan tersebut merupakan suatu informasi. Jadi, sebenarnya akuntansi itu sendiri merupakan suatu sistem informasi walaupun dikerjakan manual tanpa computer (Jogiyanto 2009).

\section{Komdanas}

Komunikasi data nasional (Komdanas) merupakan sebuah aplikasi yang berfungsi utama sebagai media penyimpanan dan database sentral berisi data-data aset, keuangan, dan remunerasi. Aplikasi ini dikembangkan pada akhir tahun 2011. Proses pengiriman data, penyimpanan data, monitoring data, dan penyusunan laporan aset, keuangan, dan remunerasi dilakukan melalui komdanas guna meningkatkan kecepatan, ketepatan, dan kelengkapan data dan laporan aset, keuangan, dan remunerasi, mengurangi beban kerja, serta meningkatkan 
produktivitas dan efektifitas setiap satuan kerja.

\section{Rerangka Konseptual Pengembangan Hipotesis}

Model proses dan hubungan kausal tersebut, dapat dijelaskan sebagai berikut: kualitas informasi (information quality) dan kualitas sistem (system quality) serta kualitas pelayanan (service quality) secara mandiri mempengaruhi baik penggunaan (use) maupun kepuasan pengguna (user satisfaction).

dan Penggunaan dan kepuasan pengguna mempengaruhi manfaat bersih (net benefits) yang merupakan penggabungan dari dampak individu dan dampak organisasi (DeLone dan McLean 2003).
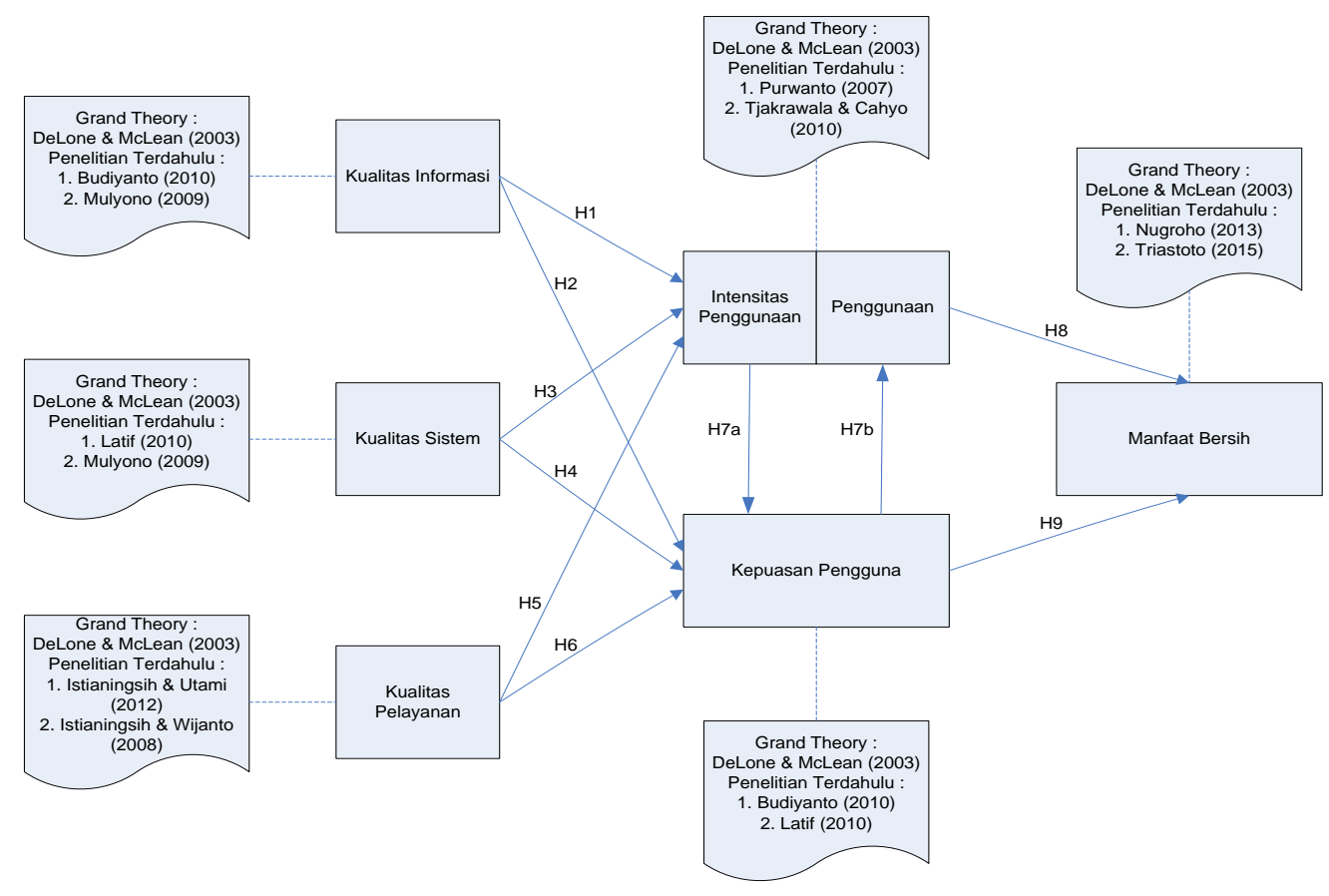

Gambar 3. Rerangka Konseptual

Rerangka konseptual pada Gambar 3 di atas menunjukkan arah bolak-balik dari penggunaan dan kepuasan pengguna. Pengaruh mutual seperti ini tidak dapat diuji bersamaan (Livari 2005; Jogiyanto 2007), sehingga harus diuji dua kali yaitu menjadi model 1 seperti pada gambar 4 yang mengasumsikan pengaruh dari penggunaan ke kepuasan pengguna (H7a) dan model 2 seperti pada Gambar 5 yang mengasumsikan pengaruh dari kepuasan pengguna ke penggunaan $(\mathrm{H} 7 \mathrm{~b})$.

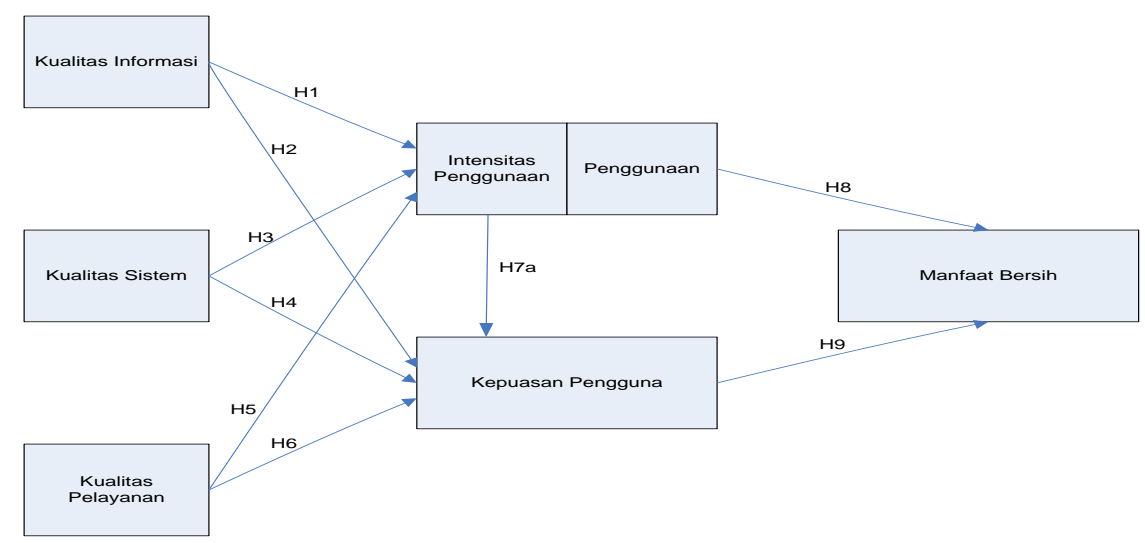

Gambar 4. Penelitian Model 2 


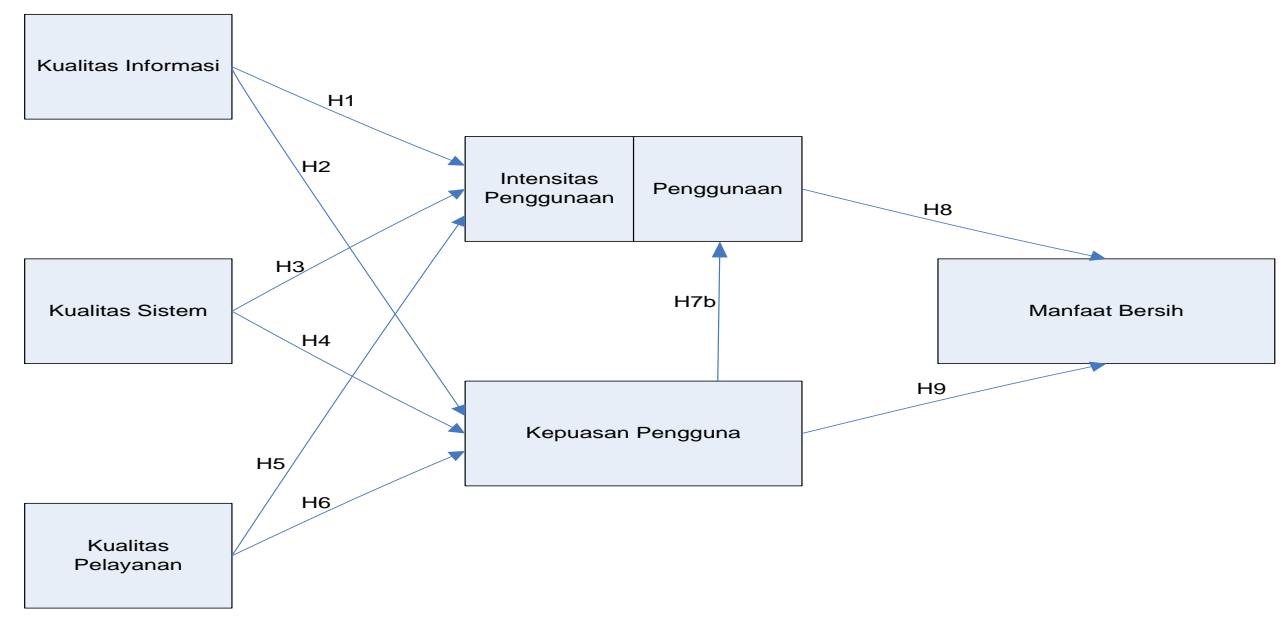

Gambar 5. Penelitian Model 2

Penelitian DeLone dan McLean (2003) menyatakan bahwa kualitas informasi (information quality) memiliki dampak yang signifikan terhadap penggunaan (use), Subramanian (2005) dalam Widodo, dkk (2013) menyatakan ada asosiasi yang signifikan antara kualitas informasi (information quality) dan penggunaan sistem (use), Livari (2005) menyebutkan kualitas informasi (information quality) yang dihasilkan oleh sistem tidak berpengaruh secara signifikan terhadap intensitas penggunaan (use), sedangkan Radityo dan Zulaikha (2007) menyatakan kualitas informasi (information quality) tidak berpengaruh secara signifikan terhadap (use). Jika output sistem yang berupa informasi memiliki kualitas yang baik maka kepuasan pengguna mudah didapatkan. Atas dasar uraian tersebut, maka penelitian ini mengajukan hipotesa kesatu sebagai berikut: Kualitas informasi (information quality) berpengaruh positif terhadap penggunaan (use).

Pengguna sistem informasi tentunya berharap bahwa dengan menggunakan sistem tersebut mereka akan memperoleh informasi yang mereka butuhkan. Karakteristik informasi yang dihasilkan suatu sistem informasi tertentu, dapat saja berbeda dengan informasi dari sistem informasi yang lain. Sistem informasi yang mampu menghasilkan informasi yang tepat waktu, akurat, sesuai kebutuhan, dan relevan serta memenuhi kreiteria dan ukuran lain tentang kualitas informasi, akan berpengaruh terhadap kepuasan penggunanya. Semakin tinggi kualitas informasi yang dihasilkan statu sistem informasi, diprediksi akan berpengaruh terhadap semakin tingginya kepuasan pengguna akhir suatu sistem informasi. Berdasarkan uraian diatas diajukan hipotesis kedua bahwa: Kualitas informasi (information quality) berpengaruh positif terhadap kepuasan pengguna (user satisfaction).

Menurut DeLone dan McLean (2003) bahwa kualitas sistem (system quality) memiliki dampak yang signifikan terhadap penggunaan (use). Sedangkan penelitian Livari (2005) menyatakan bahwa kualitas sistem (system quality) tidak berpengaruh terhadap intensitas penggunaan (use), penelitian Subramanian (2005) dalam Widodo, dkk (2013) menyatakan bahwa tidak ada asosiasi yang signifikan antara kualitas sistem (system quality) dan intensitas penggunaan (intention of use). Radityo dan Zulaikha (2007) juga menyatakan bahwa kualitas sistem (system quality) tidak berpengaruh secara signifikan terhadap intensitas penggunaan (use). Kualitas sistem akan mempengaruhi penggunaan sistem, apabila kualitas sistem baik maka pengguna akan merasa nyaman menggunakan sistem. Berdasarkan uraian diatas diajukan hipotesis ketiga bahwa: Kualitas sistem (system quality) berpengaruh positif terhadap penggunaan (use).

Ukuran kepuasan pengguna pada sistem komputer dicerminkan oleh kualitas sistem yang dimiliki (Guimaraes, 
Igbaria, dan Lu 1992; Yoon, Guimaraes, danO'Neal (1995) dalam Istianingsih (2012). Apabila kualitas sistem informasi baik menurut persepsi pemakianya, maka mereka akan cenderung merasa puas dalam menggunakan sistem tersebut. Semakin tinggi kualitas sistem informasi yang digunakan, diprediksi akan berpengaruh terhadap semakin tingginya tingkat kepuasan pengguna akhir sistem informasi tersebut. Berdasarkan uraian di atas penelitian ini menghipotesakan dalam hipotesa keempat (H4) bahwa semakin tinggi kualitas paket program aplikasi (software) akuntansi yang digunakan, akan meningkatkan kepuasan pengguna menurut mereka. Berdasarkan uraian diatas diajukan hipotesis keempat bahwa: Kualitas sistem (system quality) berpengaruh positif terhadap kepuasan pengguna (user satisfaction).

Ada hubungan lemah antara anggota the IS support dengan frekuensi dan keinginan penggunaan sistem Choe (1996) dalam Suryawan (2013). Ada studi yang memeriksa bahwa pemberian training dan pendidikan kepada pengguna dengan penggunaan sistem mempunyai hubungan yang tidak signifikan antara frekuensi dan keinginan penggunaan (Petter, DeLone, \&McLean, 2008). Sebuah studi tentang knowledge management systems ditemukan bahwa kualitas layanan tidak bisa diprediksi untuk maksud penggunaan Halawi, et al (2007) dalam Suryawan (2013). Pada level organisasi, keefektifan peran staf teknikal (kualitas layanan) berhubungan positif dengan penggunaan sistem. Caldeira \& Ward (2003) melakukan penelitian pada UKM di Portugal menemukan kompetensi staf support, vendor support dan ketersediaan training mempengaruhi penggunaan dan adopsi sistem informasi. Berdasarkan uraian diatas diajukan hipotesis kelima bahwa: Kualitas pelayanan (service quality) berpengaruh positif terhadap penggunaan (use).

Kualitas layanan merupakan persepsi pengguna atas jasa yang diberikan oleh penyedia paket program aplikasi akuntansi. Pada awalnya ukuran kualitas layanan ini didesain untuk mengukur kepuasan pelanggan oleh Parasuraman, et. al (1985) dalam Iranto
(2012). Mereka mendefinisikan kualitas layanan sebagai perbandingan antara harapan pelanggan dan persepsi mereka tentang kualitas layanan pelanggan yang diberikan. Myers, et. al. (2007) menyarankan perlunya menambahkan variabel kualitas layanan dalam mengukur keberhasilan suatu sistem informasi. Dengan menggunakan instrumen pengukuran kualitas layanan yang dibangun oleh Parasuraman,et. al. (1985) dalam Iranto (2012), menguji hubungan antara kualitas layanan dan kepuasan pengguna akhir sistem informasi. Hasil penelitian mereka menunjukkan bahwa instrumen pengukuran untuk kualitas layanan memiliki validitas yang baik untuk digunakan dalam riset sistem informasi. Atas dasar uraian tersebut, maka penelitian ini mengajukan hipotesa keenam sebagai berikut: Kualitas pelayanan (service quality) berpengaruh positif terhadap kepuasan pengguna (user satisfaction).

Penggunaan yang berulang-ulang ini dapat dimaknai bahwa penggunaan yang dilakukan bermanfaat bagi pengguna. Tingginya derajat manfaat yang diperoleh mengakibatkan pengguna akan lebih puas. DeLone dan McLean (1992) menyatakan bahwa hubungan antara penggunaan dan kepuasan pengguna merupakan hubungan yang timbal balik (reciprocally). Semakin sering pengguna memakai sistem informasi biasanya diikuti oleh semakin banyak tingkat pembelajaran (degree of learning) yang didapat pengguna mengenai sistem informasi (McGill et al. 2003), oleh karenanya hipotesis 7 di tuliskan menjadi hipotesis 7 a yaitu Penggunaan (use) berpengaruh positif terhadap kepuasan pengguna (user satisfaction). dan hipotesis $7 \mathrm{~b}$ yaitu Kepuasan pengguna (user satisfaction) berpengaruh positif terhadap penggunaan (use).

$\begin{array}{lrr}\text { Studi } & \text { terdahulu } & \text { menemukan } \\ \text { penggunaan } & \text { sistem } & \text { informasi } \\ \text { berhubungan } & \text { positif } & \text { terhadap }\end{array}$ pengambilan keputusan. Burton-Jones \& Straub (2006) menemukan hubungan yang signifikan antara penggunaan sistem dan task performance dan mengidentifikasikan hubungan antara maksud penggunaan dan manfaat bersih diukur dengan peningkatan kinerja 
pekerjaan. Banyak studi yang menemukan hubungan yang signifikan antara penggunaan sistem dan manfaat bersih. (Petter, DeLone \& McLean 2008) menyebutkan waktu proses self reported menggunakan sistem informasi diantara manajer berkorelasi positif terhadap pengambilan keputusan di perusahaan Jerman. Sementara Zhu \& Kraemer (2005) menemukan penggunaan sistem informasi untuk e-businesses mempunyai hubungan positif yang berdampak pada nilai developed dan developing countries. Penggunaan executive IS berdampak pada produktifitas, pengambilan keputusan, dan biaya internal secara positif. Gelderman (1998) dalam Agustiani (2010) menemukan penggunaan sistem, dalam hal durasi waktu, tidak berhubungan signifikan terhadap peningkatan penghasilan dan manfaat. Atas dasar uraian tersebut, maka penelitian ini mengajukan hipotesa kedelapan sebagai berikut Penggunaan (use) berpengaruh positif terhadap manfaat bersih (net benefits).

$\begin{array}{rrr}\text { Manfaat bersih (net benefits) } & \text { (nistem }\end{array}$
informasi terhadap kinerja individu organisasi dimana STI diterapkan. Hal ini merupakan alasan yang menguatkan bahwa keberadaan STI dapat memberikan manfaat bersih (net benefits) bagi individu maupun organisasi berupa produktifitas dan efektifitas kinerja. DeLone dan McLean (2003) menyatakan bahwa kepuasan pengguna (user satisfaction) merupakan prediktor yang signifikan bagi net benefits. Livari (2005) menyatakan bahwa kepuasan pengguna (user satisfaction) juga prediktor yang signifikan bagi perceived individual impact. Hasil yang tidak sama ditunjukkan oleh Subramanian (2005) dalam Widodo, dkk (2013) bahwa tidak ada asosiasi yang positif antara kepuasan pengguna (user satisfaction) dan individual impact/net benefits. Radityo dan Zulaikha (2007) bahwa tidak ada hubungan yang signifikan antara kepuasan pengguna (user satisfaction) dan individual impact/net benefits. Kepuasan pengguna atas sistem yang dapat memenuhi kebutuhan pekerjaan akan mempengaruhi kinerja organisasi. Semakin tinggi kepuasan pengguna maka tingkat kinerja organisasi akan semakin tinggi. Berdasarkan uraian tersebut maka hipotesis yang diajukan sebagai berikut: Kepuasan pengguna (user satisfaction) berpengaruh positif terhadap manfaat bersih (net benefits).

\section{METODE PENELITIAN}

\section{Jenis Penelitian}

Penelitian ini merupakan penelitian dengan konstruk multidimensional yaitu penggunaan $(\mathrm{P})$ dan kepuasan pengguna (KP) diukur dengan konstruk kualitas informasi (KI), kualitas sistem (KS), kualitas pelayanan (KPel) yang akan diukur pengaruhnya terhadap manfaat bersih (MB) (Jogiyanto 2011:89).

\section{Lokasi dan Waktu Penelitian}

Penelitian dilakukan pada 17 satuan kerja dibawah Korwil Pengadilan Tinggi Mataram yang merupakan bagian dari Mahkamah Agung RI, sedangkan waktu penelitian dilakukan pada bulan Mei sampai dengan bulan Juli tahun 2015.

\section{Populasi dan Sampel}

Dalam penelitian ini populasinya adalah 17 satuan kerja pengadilan di bawah Korwil Pengadilan Tinggi Mataram yang melakukan aktivitas operasionalnya menggunakan komdanas. Sampel atas responden dilakukan dengan judgment sampling. Menurut Uma Sekaran (2006:137), judgment sampling adalah teknik pengambilan sampel berdasarkan pertimbangan/ kriteria tertentu melibatkan pemilihan subjek yang berada di tempat yang paling menguntungkan atau dalam posisi terbaik untuk memberikan informasi yang diperlukan.

Kriteria responden dalam penelitian ini adalah pengguna sistem informasi akuntansi komdanas sesuai dengan pocketbook yang dikeluarkan Mahkamah Agung yaitu Kuasa Pengguna Anggaran (KPA), Pejabat Pembuat Komitmen (PPK), Kasubbag (Keuangan, Umum, Kepegawaian) dan staf (Keuangan, Umum, Kepegawaian) dalam Korwil Pengadilan Tinggi Mataram sejumlah 114 responden. 
Definisi Operasional Variabel

Penelitian ini memfokuskan pada kesuksesan sistem informasi akuntansi (SIA) pada konstruk penggunaan (P) dan kepuasan pengguna (KP) yang pada akhirnya berpengaruh pada manfaat bersih (MB). Variabel penelitian mengikuti DeLone dan McLean yang terdiri dari 6 konstruk yang diklasifikasikan ke dalam variabel eksogen dan variabel endogen. Variabel eksogen terdiri atas kualitas informasi (KI) dan kualitas sistem (KS), dan kualitas pelayanan (KPel) sedangkan variabel endogen terdiri atas penggunaan $(\mathrm{P})$, kepuasan pengguna (KP), dan manfaat bersih (MB).

Tabel 1. Definisi Operasional

\begin{tabular}{|c|c|c|c|}
\hline Variabel & Indikator & Skala & Sumber \\
\hline Kualitas Informasi & $\begin{array}{ll}\text { - } & \text { Accuracy } \\
\text { - } & \text { Timeliness } \\
\text { - } & \text { Relevance } \\
\text { - } & \text { Informativeness } \\
\text { - } & \text { Competitiveness }\end{array}$ & - Likert & $\begin{array}{l}\text { Weber (1999) } \\
\text { Kuesioner : } \\
\text { Istianingsih \& Wijanto } \\
(2008)\end{array}$ \\
\hline Kualitas Sistem & $\begin{array}{ll}- & \text { Ease of use } \\
\text { - } & \text { Reliability } \\
\text { - } & \text { Respon Time } \\
\text { - } & \text { System } \\
& \text { Flexibility } \\
\text { - } & \text { Security }\end{array}$ & - Likert & $\begin{array}{l}\text { Hamilton \& Chervany } \\
(1981) \\
\text { Kuesioner: } \\
\text { Radityo \& Zulaikha } \\
\text { (2007) }\end{array}$ \\
\hline Kualitas Pelayanan & $\begin{array}{ll}\text { - } & \text { Assurance } \\
\text { - Empathy } \\
\text { - }\end{array}$ & - Likert & $\begin{array}{l}\text { DeLone dan McLean } \\
\text { (2003) } \\
\text { Kuesioner: } \\
\text { Haryanta (2008) } \\
\end{array}$ \\
\hline Penggunaan & - Nature Of Use & - Likert & $\begin{array}{l}\text { Davis (1989) } \\
\text { Kuesioner: } \\
\text { Tjakrawala \& Cahyo } \\
(2010)\end{array}$ \\
\hline $\begin{array}{l}\text { Kepuasan } \\
\text { Penggunaan }\end{array}$ & $\begin{array}{ll}\text { - } & \text { Content } \\
\text { - } & \text { Accuracy } \\
\text { - } & \text { Format } \\
\text { - } & \text { Easy Of Use } \\
\text { - } & \text { Timeliness }\end{array}$ & - Likert & $\begin{array}{l}\text { Weber (1999) } \\
\text { Kuesioner: } \\
\text { Istianingsih \& Wijanto } \\
(2008)\end{array}$ \\
\hline Manfaat Bersih & $\begin{array}{ll}\text { - } & \text { Productivity } \\
\text { - } & \text { Efectivity }\end{array}$ & - Likert & $\begin{array}{l}\text { DeLone dan McLean } \\
\text { (2003) } \\
\text { Kuesioner: } \\
\text { Haryanta (2008) }\end{array}$ \\
\hline
\end{tabular}

\section{Prosedur Analisis Data}

Analisis statistik yang digunakan adalah model struktural dengan alat analisis Partial Least Square (PLS) menggunakan software SmartPLS version 3.O.M3. PLS (Partial Least Square) merupakan analisis persamaan struktural (SEM) berbasis varian yang secara simultan dapat melakukan pengujian model pengukuran sekaligus pengujian model struktural. Lebih lanjut, Wold (1998) dalam Latan dan Ghozali (2012:6) menjelaskan bahwa PLS adalah metode analisis yang powerfull dan sering disebut juga sebagai soft modeling karena meniadakan asumsi-asumsi Square) regresi.

Menurut Latan dan Ghozali (2012:47), tahapan analisis menggunakan PLS-SEM setidaknya setiap tahapan akan berpengaruh terhadap tahapan selanjutnya. Tahapan tahapan tersebut diantaranya (1) Konseptualisasi model, (2) Menentukan metode analisa algorithm, (3) Menentukan metode resampling, (4) Menggambar diagram jalur, dan (5)Evaluasi model 


\section{PEMBAHASAN}

\section{Gambaran Umum Komdanas Mahkamah Agung}

Penelitian ini menggunakan data primer mengenai sistem informasi akuntansi komunikasi data nasional (Komdanas) yang digunakan oleh seluruh satuan kerja di lingkup Mahkamah Agung dalam menyelenggarakan akuntansi dan pertanggungjawaban pelaksanaan anggaran/barang. Objek penelitian ini berupa manfaat bersih (MB) yang didapatkan dari pemanfaatan sistem informasi akuntansi komdanas dengan variabel kualitas informasi (KI), kualitas sistem (KS), dan kualitas pelayanan (KPel) yang di proksikan dengan penggunaan $(\mathrm{P})$ dan kepuasan pengguna (KP). Subjek penelitian ini adalah seluruh satuan kerja dibawah korwil Pengadilan Tinggi Mataram, seperti yang terdapat dalam tabel 2 berikut ini :

Tabel 2. Daftar satuan kerja Korwil Pengadilan Tinggi Mataram

\begin{tabular}{clllll}
\hline No & \multicolumn{1}{c}{ Nama Daerah } & No & \multicolumn{1}{c}{ Nama Daerah } & No & Nama Daerah \\
\hline 1 & PT Mataram & 7 & PN Selong & 13 & PA Dompu \\
2 & PTA Mataram & 8 & PA Selong & 14 & PN Raba Bima \\
3 & PN Mataram & 9 & PN Sumbawa Besar & 15 & PA Raba Bima \\
4 & PA Mataram & 10 & PA Sumbawa Besar & 16 & PA Giri Menang \\
5 & PN Praya & 11 & PA Taliwang & 17 & PTUN Mataram \\
6 & PA Praya & 12 & PN Dompu & &
\end{tabular}

\section{Gambaran Umum Responden}

Dengan menggunakan metode pengumpulan data melalui kuesioner, terdapat 102 jawaban responden yang layak diuji dan diolah lebih lanjut. Jumlah kuesioner yang diolah dari masing-masing satuan kerja (satker) adalah sebagai berikut :

Tabel 3. Jumlah Kuesioner Yang Kembali dan Layak Diolah

\begin{tabular}{lr}
\hline \multicolumn{1}{c}{ Keterangan } & Jumlah \\
\hline Total Kuesioner yang disampaikan & 114 \\
Total kuesioner yang tidak kembali & 8 \\
Total kuesioner yang kembali & 106 \\
Kuesioner yang tidak bisa digunakan (tidak diisi) & 4 \\
Total kuesioner yang bisa diolah & 102 \\
\hline
\end{tabular}

Untuk mengenal masing-masing objek dalam penelitian ini berikut ini akan dideskripsikan profil dari masingmasing subjek dalam penelitian ini dan karakteristik responden yang meliputi jabatan, tingkat pendidikan, jenis kelamin dan umur. Responden yang berpartisipasi dalam penelitian ini dari segi kelamin dominan pria dibanding wanita. Sedangkan dari usia dikatakan sudah sangat matang, hal ini ditunjukkan dengan usia terbanyak responden pada kisaran umur 31-40 tahun sebanyak 49 orang $(48,00 \%)$. Untuk tingkat pendidikan dapat dikatakan bahwa pengguna yang berhubungan dengan komdanas yang menjadi responden cukup tinggi, hal ini ditunjukkan dengan dominasi tingkat pendidikan mereka yang pada tingkat Sarjana dan sederajat sebanyak 63 orang $(63,74 \%)$. Jabatan staf jauh lebih banyakyang menggunakan komdanas yaitu sebanyak 89 orang $(87,25 \%)$.

\section{Evaluasi outer model}

Langkah awal evaluasi model dengan PLS dalam penelitian ini, seperti yang telah dijabarkan pada BAB 3 adalah evaluasi pada model pengukuran/measurement (outer model). Evaluasi outer model yang dilakukan yaitu evaluasi konstruk dengan indikator reflektif. Hasil kalkulasi awal algoritma PLS untuk kedua model penelitian ini adalah sebagai berikut : 


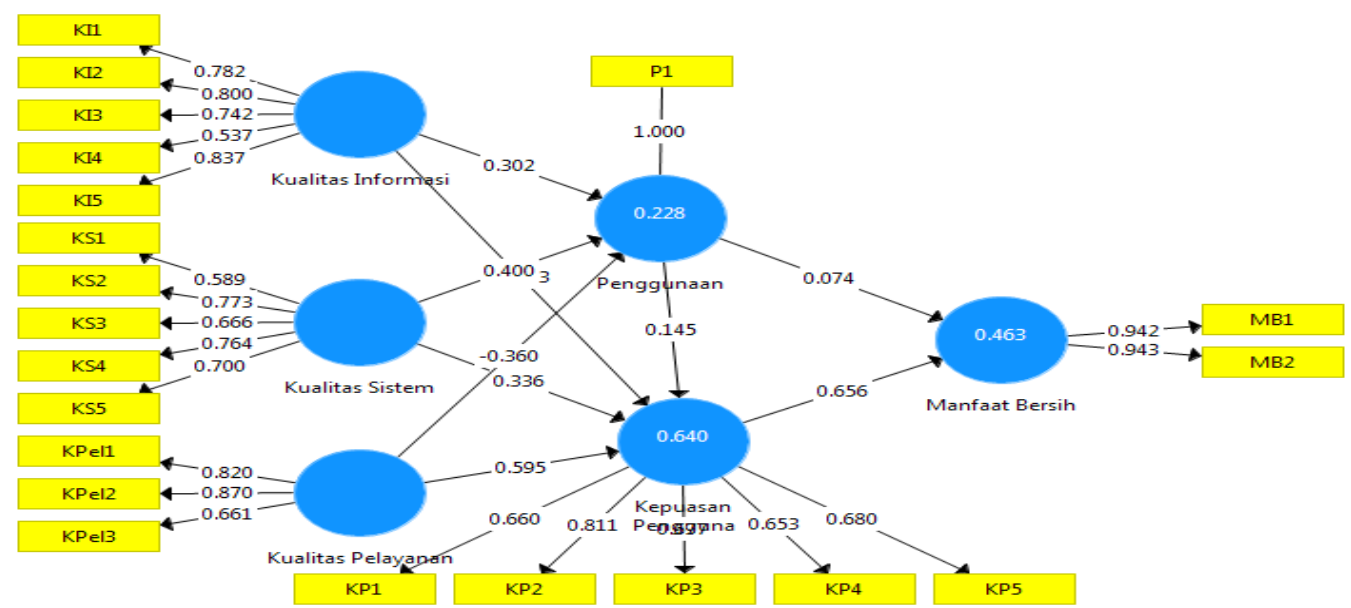

Gambar 6. Hasil Kalkulasi Algoritma PLS Model 1

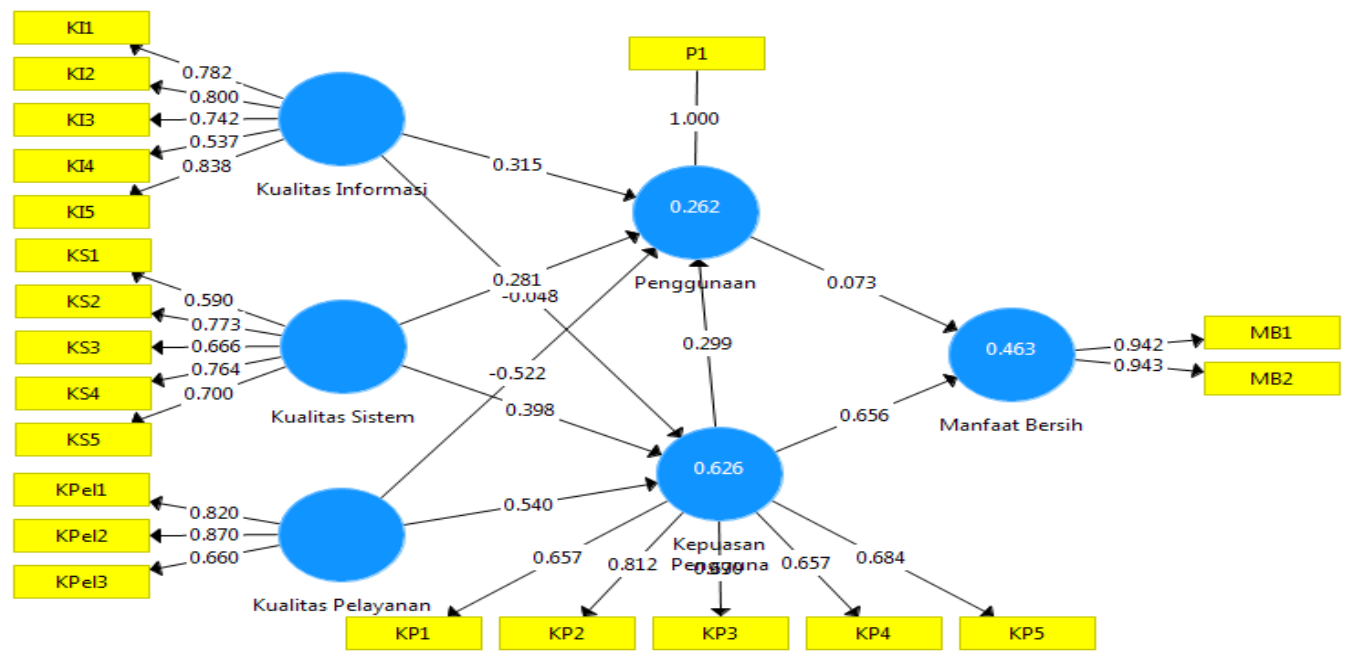

Gambar 7. Hasil Kalkulasi Algoritma PLS Model 2

Berdasarkan gambar 6 dan 7 dapat dilihat loading factor untuk indikator MB1 dan MB2 memiliki loading factor $>0,5$ yang artinya MB1 dan MB2 memenuhi syarat untuk dijadian indikator pengukur konstruk manfaat bersih (MB), sehingga dapat dinyatakan konstruk manfaat bersih (MB) sudah memenuhi uji Convergent Validity karena loading factor-nya > 0,5 .

\section{Evaluasi Inner Model}

\section{R-square}

Konstruk variabel manfaat bersih (MB) dapat diterangkan oleh konstruk variabel $\mathrm{KP}$ dan $\mathrm{P}$ sebesar $46,30 \%$ atau masuk dalam kategori moderat karena nilai $R$ -

square $0,463<0,64$ dan $>0,33$. Sementara itu 53,7 \% variabel MB diterangkan oleh variabel lain yang tidak diteliti.

Tabel 4. R-square Model 1

\begin{tabular}{lcr}
\hline \multirow{2}{*}{ Variabel } & \multicolumn{2}{c}{ R Square } \\
\cline { 2 - 3 } & Model 1 & Model 2 \\
\hline Kepuasan Pengguna & 0,640 & 0,626 \\
Manfaat Bersih & 0,463 & 0,463 \\
Penggunaan & 0,228 & 0,262 \\
\hline
\end{tabular}




\section{Q-Square}

Hasil menunjukkan bahwa model mempunyai predictive relevance yang baik $(Q$-Square $=0,850757($ Model 1$))$ dan Model 1 :

$$
\begin{aligned}
\mathrm{Q}^{2} & =1-\left(1-\mathrm{R}_{1}^{2}\right)\left(1-\mathrm{R}_{2}^{2}\right)\left(1-\mathrm{R}_{3}^{2}\right) \\
& =1-(1-0,64)(1-0,463)(1-0,228) \\
& =1-0,14924 \\
& =0,850757
\end{aligned}
$$

$(Q$-Square $=0,851782($ Model 2$)$, dimana semakin mendekati 1 berarti model semakin baik.

Model 2 :

\begin{tabular}{|c|c|c|c|c|c|c|c|}
\hline & $\begin{array}{l}\text { Original } \\
\text { Sample } \\
\text { (O) }\end{array}$ & $\begin{array}{c}\text { Sample } \\
\text { Mean (M) }\end{array}$ & $\begin{array}{c}\text { Standard } \\
\text { Error } \\
\text { (STERR) }\end{array}$ & $\begin{array}{l}\text { T Statistics } \\
(|\mathrm{O} / \mathrm{STERR}|)\end{array}$ & P Values & Hipotesis & Keterangan \\
\hline $\mathrm{KI} \quad>\mathrm{P}$ & 0,302 & 0,296 & 0,117 & 2,576 & 0,010 & $\mathrm{H} 1$ & Diterima \\
\hline $\mathrm{KI} \quad \rightarrow \mathrm{KP}$ & $-0,093$ & $-0,085$ & 0,128 & 0,727 & 0,468 & $\mathrm{H} 2$ & Ditolak \\
\hline $\mathrm{KS}->\mathrm{P}$ & 0,4 & 0,404 & 0,106 & 3,785 & 0,000 & H3 & Diterima \\
\hline $\mathrm{KS}->\mathrm{KP}$ & 0,336 & 0,343 & 0,113 & 2,978 & 0,003 & $\mathrm{H} 4$ & Diterima \\
\hline KPel -> P & $-0,36$ & $-0,359$ & 0,122 & 2,950 & 0,003 & H5 & Ditolak \\
\hline KPel -> KP & 0,595 & 0,595 & 0,081 & 7,308 & 0,000 & H6 & Diterima \\
\hline $\mathrm{P}->\mathrm{KP}$ & 0,145 & 0,135 & 0,056 & 2,573 & 0,010 & $\mathrm{H} 7 \mathrm{a}$ & Diterima \\
\hline $\mathrm{P}->\mathrm{MB}$ & 0,074 & 0,077 & 0,082 & 0,899 & 0,369 & H8 & Ditolak \\
\hline $\mathrm{KP}$-> MB & 0,656 & 0,658 & 0,059 & 11,05 & 0,000 & H9 & Diterima \\
\hline
\end{tabular}

$$
\begin{aligned}
\mathrm{Q}^{2} & =1-\left(1-\mathrm{R}_{1}^{2}\right)\left(1-\mathrm{R}_{2}^{2}\right)\left(1-\mathrm{R}_{3}^{2}\right) \\
& =1-(1-0,626)(1-0,463)(1-0,262) \\
& =1-0,148218 \\
& =0,851782
\end{aligned}
$$

\section{Uji Hipotesis}

Tabel 5. Path Coefficients (Mean, STDEV, T-Values) Model 1

Tabel 6. Path Coefficients (Mean, STDEV, T-Values) Model 2

\begin{tabular}{lrrrrrrr}
\hline & $\begin{array}{c}\text { Original } \\
\text { Sample } \\
(\mathrm{O})\end{array}$ & $\begin{array}{c}\text { Sample } \\
\text { Mean (M) }\end{array}$ & $\begin{array}{c}\text { Standard } \\
\text { Error } \\
\text { (STERR) }\end{array}$ & $\begin{array}{c}\text { T Statistics } \\
(\mid \text { O /STERR })\end{array}$ & P Values & Hipotesis & Keterangan \\
\hline KI -> P & 0,315 & 0,318 & 0,128 & 2,462 & 0,014 & H1 & Diterima \\
KI -> KP & $-0,048$ & $-0,042$ & 0,123 & 0,390 & 0,696 & H2 & Ditolak \\
KS -> P & 0,281 & 0,28 & 0,118 & 2,387 & 0,017 & H3 & Diterima \\
KS -> KP & 0,398 & 0,401 & 0,108 & 3,701 & 0,000 & H4 & Diterima \\
KPel -> P & $-0,522$ & $-0,542$ & 0,138 & 3,784 & 0,000 & H5 & Ditolak \\
KPel -> KP & 0,54 & 0,543 & 0,071 & 7,638 & 0,000 & H6 & Diterima \\
KP -> P & 0,299 & 0,322 & 0,132 & 2,260 & 0,024 & H7b & Diterima \\
P -> MB & 0,073 & 0,07 & 0,086 & 0,849 & 0,397 & H8 & Ditolak \\
KP -> MB & 0,656 & 0,662 & 0,061 & 10,804 & 0,000 & H9 & Diterima \\
\hline
\end{tabular}

\section{Pengaruh Kualitas Informasi (KI)} Terhadap Penggunaan (P)

Penerimaan terhadap hipotesis satu (H1) mengindikasikan bahwa kualitas informasi komdanas memberikan bukti dapat meningkatkan penggunaan komdanas. Teori DeLone dan McLean (2003) juga menunjukkan bahwa kualitas informasi berpengaruh terhadap penggunaan sistem informasi. Hasil di lapangan juga menunjukkan bahwa kualitas informasi komdanas secara keseluruhan dinilai baik oleh kebanyakan responden, seperti kelengkapan, penyajian informasi, keakuratan, relevan dan ketepatan waktu. Hasil ini sama dengan hasil penelitian Istianingsih dan Wijanto (2008) yang menyatakan kualitas informasi berpengaruh positif terhadap penggunaan sistem informasi. Istianingsih dan Wijanto (2008) dalam penelitiannya menunjukkan bahwa semakin baik kualitas informasi yang dihasilkan, akan menyebabkan pengguna sistem tidak merasa enggan untuk melakukan penggunaan kembali (reuse) dengan demikian penggunaan sistem akan meningkat. Hasil penelitian ini tidak 
mendukung hasil penelitian Radityo dan Zulaikha (2007) dan Budiyanto (2009) yang membuktikan tidak adanya pengaruh positif dari kualitas informasi terhadap penggunaan.

\section{Pengaruh Kualitas Informasi (KI) Terhadap Kepuasan Pengguna (KP)}

Penolakan terhadap hipotesis dua (H2) mengindikasikan bahwa kualitas informasi komdanas tidak dapat memberikan bukti dapat meningkatkan kepuasan pengguna komdanas. Penelitian ini tidak sesuai dengan teori DeLone dan McLean (2003) yang menunjukkan kualitas informasi mempengaruhi kepuasan pengguna. Hasil di lapangan menunjukkan kualitas informasi komdanas di penelitian ini adalah informasi yang berkualitas untuk kepentingan satuan kerja dan itu dijalankan oleh pengguna (responden), namun demikian didalamnya tidak serta merta mewakili kepentingan responden secara pribadi sehingga menghasilkan hipotesis yang ditolak. Pengaruh yang negatif signifikan juga diduga disebabkan sifat penggunaan komdanas yang mandatory pada bagian tertentu khususnya bagi staf yang merupakan sebagian besar responden. Dengan demikian, dapat dikatakan kualitas informasi komdanas tidak menjadi prediktor yang baik atas konstruk kepuasan pengguna komdanas karena penggunaan informasi komdanas bersifat wajib (tidak ada pilihan lain).

Dugaan lain dari hasil wawancara hipotesis ditolak diakibatkan informasi yang dihasilkan susah direvisi, karena sistem membaca apa yang sudah diperintahkan bukan apa yang harus diselesaikan sehingga terkadang keputusan yang mengharuskan kita untuk memodifikasi laporan karena sesuatu hal yg tidak bisa diputuskan oleh sistem. Responden lain juga berargumen juga tidak semua informasi dihasilkan oleh sistem, deengan kata lain, sistem itu berguna untuk keputusan tertentu, bukan untuk keputusan menyeluruh, sebagai contoh uraian-uraian dalam Catatan atas Laporan Keuangan (CaLK) hasil dari komdanas yang masih perlu perbaikanperbaikan dari pengguna komdanas.

Hasil ini sama dengan hasil penelitian Radityo dan Zulaikha (2007) yang menyatakan kualitas informasi tidak berpengaruh terhadap kepuasan pengguna karena penggunaan informasinya yang bersifat wajib. Hasil ini bertolak belakang penelitian Mulyono (2008) dan Livari (2005) yang menyatakan bahwa tingginya derajat manfaat yang diperoleh mengakibatkan pengguna akan lebih puasyang mengindikasikan bahwa kualitas informasi yang baik (akurat, lengkap dan memilki realiabilitas yang baik) akan membentuk kepercayaaan pengguna terhadap sistem tersebut, karena mereka merasa sistem tersebut membawa kebermanfaatan bagi mereka, sehingga pengguna pun akan merasa puas.

\section{Pengaruh Kualitas Sistem (KS) Terhadap Penggunaan (P)}

Penerimaan terhadap hipotesis ketiga (H3) tersebut mengindikasikan bahwa kualitas sistem komdanas memberikan bukti dapat meningkatkan penggunaan komdanas, sesuai dengan teori DeLone dan McLean (2003) yang mengatakan bahwa kualitas sistem berpengaruh positif terhadap penggunaan. Hasil di lapangan menunjukkan tingkat penggunaan sistem tidak terlalu jauh berbeda antara satu pengguna dengan pengguna lain, walaupun perbedaan peran dalam pembagian tugas dan intensitas transaksi dalam satuan kerja tempat mereka bekerja tetapi tidak berpengaruh terhadap penggunaan antara satu pengguna dengan pengguna lainnya.

Hasil ini sejalan dengan hasil penelitian Budiyanto (2009) dan Latif (2010). Latif (2010) dalam penelitiannya menunjukkan bahwa semakin baik kualitas sistem yang digunakan, akan menyebabkan pengguna sistem tidak merasa enggan untuk melakukan penggunaan kembali (reuse), dengan demikian penggunaan sistem akan meningkat. Tetapi hasil penelitian ini tidak mendukung hasil penelitian Radityo dan Zulaikha (2007) yang membuktikan tidak adanya pengaruh positif dari kualitas sistem terhadap penggunaan. 
Pengaruh Kualitas Sistem (KS) Terhadap Kepuasan Pengguna (KP)

Penerimaan terhadap hipotesis keempat (H4) ini menandakan bahwa kualitas sistem komdanas memberikan bukti dapat meningkatkan kepuasan pengguna komdanas, sesuai dengan teori DeLone dan McLean (2003). Hasil wawancara juga menunjukkan penggunaan komdanas sesuai anjuran Mahkamah Agung dalam pengelolaan keuangan dapat menyelesaikan pekerjaan lebih cepat.

Hasil ini konsisten dengan hasil penelitian McGill, et,al. (2003) dan Budiyanto (2009) yang menyatakan bahwa kualitas sistem berpengaruh positif terhadap kepuasan penggunanya, dimana semakin baik kualitas sistem informasi, akan menyebabkan pengguna sistem informasi merasa bahwa sistem informasi tersebut kebermanfaatan bagi mereka, sehingga mereka merasa puas atas penggunaan sistem tersebut, misalnva kemudahan dalam pengoperasian. Hasil ini mungkin disebabkan karena banyaknya responden yang merasa bahwa sistem cukup baik, terutama dalam hal fleksibilitas, kemampuan mengatasi kesalahan-kesalahan, dan kemampuan berkomunikasi dengan sistem informasi lain. Hal ini terlihat dari banyaknya responden mereka yang merasa bahwa sistem mudah dipahami dan sangat memadai untuk menyelesaikan pekerjaan mereka. Hasil ini bertolak belakang dengan hasil penelitian Radityo dan Zulaikha (2007) yang membuktikan bahwa kualitas sistem tidak berpengaruh positif signifikan terhadap kepuasan penggunanya.

\section{Pengaruh Kualitas Pelayanan (KPel) Terhadap Penggunaan (P)}

Penolakan terhadap hipotesis kelima (H5) mengindikasikan bahwa kualitas pelayanan komdanas tidak dapat memberikan bukti dapat mempengaruhi penggunaan komdanas. Teori DeLone dan McLean (2003) menyatakan sebaliknya yakni kualitas pelayanan berpengaruh terhadap penggunaan. Hasil wawancara menunjukkan komdanas belum dapat memberikan bukti memenuhi kriteria empati yang meliputi kemudahan dalam berhubungan komunikasi yang baik, perhatian pribadi, dan memahami keperluan para pengguna sistem informasi. Hal ini dibuktikan dalam penelitian dengan rendahnya penilaian indikator empati dari kualitas pelayanan bila dibandingkan dengan dua indikator lainnya yaitu jaminan dan respon layanan, hal ini bisa jadi disebabkan oleh belum tersedianya layanan informasi yang dapat dilihat oleh publik diluar dari pegawai yang mempunyai hak akses aplikasi. Hasil wawancara juga mendapatkan bukti bahwa kualitas pelayanan komdanas tidak dapat memenuhi harapan pengguna mendapatkan update terhadap aturanaturan keuangan terbaru yang cenderung lama bahkan terkadang sistem menjadi error sehingga penggunaan komdanas menjadi tidak berarti karena fitur-fitur komdanas masih menggunakan aturan-aturan yang lama.

Hasil ini konsisten dengan penelitian Triastoto (2015) yang menunjukkan ada beberapa faktor negatif yang mengakibatkan kualitas pelayanan tidak berpengaruh terhadap penggunaan sistem informasi akuntansi antara lain koneksi internet yang bermasalah dan respon administrator pusat terhadap permasalahan yang tidak bisa diselesaikan melalui telpon. Hasil ini berbeda dengan hasil penelitian Purwanto (2007) dalam penelitiannya menunjukkan bahwa penggunaan sistem yang cenderung meningkat akan mendukung pemerintah dalam menerapkan pelayanan publik yang lebih baik.

\section{Pengaruh Kualitas Pelayanan (KPel) Terhadap Kepuasan Pengguna (KP)}

Penerimaan terhadap hipotesis keenam (H6) mengindikasikan bahwa kualitas pelayanan komdanas dapat memberikan bukti dapat berpengaruh positif terhadap kepuasan pengguna komdanas. Hasil ini sesuai teori DeLone dan McLean (2003) yang menunjukkan ada pengaruh kualitas pelayanan dan kepuasan pengguna. penggunaan. Nilai positif dapat di artikan apabila kualitas 
pelayanan komdanas semakin baik, maka kepuasan pengguna komdanas semakin meningkat. Pengaruh positif kualitas pelayanan di lapangan juga dapat terlihat, dimana dalam pelaksanaannya pengguna komdanas diberikan kebebasan untuk memberikan masukan tentang sistem informasi yang digunakan sehingga sistem sesuai dengan harapan pengguna yang berpengaruh terhadap kepuasan pengguna komdanas.

Hasil penelitian ini sesuai dengan seluruh penelitian terdahulu, diantaranya penelitian Istiningsih dan Utami (2009) dan Purwanto (2007) yang memberikan bukti empiris bahwa kualitas pelayanan berpengaruh positif dan signifikan terhadap kepuasan pengguna.

\section{Pengaruh Penggunaan (P) Terhadap Kepuasan Pengguna (KP)}

Penerimaan hipotesis ini konsisten dengan teori DeLone dan McLean (2003), dimana penggunaan komdanas yang berulang-ulang ini dapat dimaknai bahwa penggunaan komdanas yang dilakukan bermanfaat bagi pengguna komdanas. Tingginya derajat manfaat yang diperoleh mengakibatkan pengguna akan lebih puas. Hasil di lapangan juga menunjukkan tingginya tingkat penggunaan sistem informasi akuntansi mempengaruhi kepuasan pegawai menggunakan komdanas. Hasil ini konsisten dengan hasil penelitian Pratiwi dan Cofriyanti (2013)yang menyatakan bahwa penggunaan sistem informasi berpengaruh positif terhadap kepuasan penggunanya. Hasil ini berbeda dengan penelitian Purwanto (2007) dan Radityo dan Zulaikha (2007), dimana penggunaan mandatory sistem informasi tidak dapat digunakan untuk mengukur puas tidaknya pengguna sistem. Hal ini terjadi karena kepuasan pengguna merupakan sikap yang muncul dari dalam dan bukan terjadi karena paksaan seperti pada implementasi sistem informasi mandatory.

\section{Pengaruh Kepuasan Pengguna Terhadap Penggunaan (P)}

Penerimaan terhadap hipotesis tujuh b (H7b) tersebut mengindikasikan bahwa kepuasan pengguna komdanas memberikan bukti dapat meningkatkan penggunaan komdanas yang dapat berbeda-beda antara satu pengguna dengan pengguna seperti yang telah disampaikan pada penjelasan sebelumnya. Hasil ini sesuai dengan teori DeLone dan McLean (2003). Di sisi lain secara keseluruhan menunjukkan responden merasa puas atas penggunaan komdanas, terutama karena penggunaannya yang mudah dipahami dan memadai untuk menyelesaikan pekerjaan mereka, sehingga disini tingkat kepuasan pengguna yang dirasakan mempengaruhi intensitas penggunaan mereka terhadap sistem yang mereka gunakan.

Hasil ini sesuai dengan apa yang diungkapkan Livari (2005) dan Latif (2010) yang sama-sama memperoleh hasil bahwa terdapat pengaruh dari kepuasan pengguna terhadap intensitas penggunaan, dimana semakin pengguna sistem informasi merasa bahwa mereka memperoleh kebermanfaatan (usefulness) dari penggunaan sistem kemudahan pemahaman dan sangat memadainya sistem untuk menyelesaikan pekerjaan mereka, pegawai akan tidak merasa enggan untuk melakukan penggunaan kembali (reuse), dengan demikian intensitas penggunaan sistem akan meningkat. Hasil penelitian Radityo dan Zulaikha (2007) menolak hasil penelitian ini, dimana karena sifat penggunaan sistem yang bersifat mandatory dalam penelitiannya membuat pengguna tidak memiliki pilihan lain dalam penggunaan sistem, sehingga kepuasan pengguna tidak berpengaruh terhadap intensitas penggunaan.

\section{Pengaruh Penggunaan (P) Terhadap Manfaat Bersih (MB)}

Penolakan terhadap hipotesis kedelapan (H8) tersebut mengindikasikan bahwa dalam penelitian ini inensitas penggunaan komdanas tidak memberikan bukti dapat memberikan manfaat bersih. Hasil penelitian ini berbeda dengan teori DeLone dan Mclean (2003) yang menyatakan penggunaan sistem informasi akan berpengaruh terhadap manfaat bersih.

Hasil wawancara menunjukkan 
penolakan hipotesis ini mungkin disebabkan karena penggunaan bisa lama mengingat banyaknya satuan kerja di bawah Mahkamah Agung yang menggunakan komdanas sehingga server melambat yang berakibat lama dalam pengoperasian komdanas dan berulangulang sehingga menjadikan penggunaan komdanas menjadi tidak efektif, artinya komdanas yg bersifat mandatory yamg ternyata tidak dapat dihubungkan dengan kesuksesan sistem. Mandatory bukan berarti sistem tersebut sukses digunakan sesuai dengan tujuan satuan kerja namun hanya dalam rangka menjalankan tugas saja, selain itu tingkat penggunaan sistem yang dapat berbeda-beda antara satu pengguna dengan pengguna lain. Perbedaan tersebut dikarenakan responden sendiri lebih menggunakan komdanas hanya pada saat kewajiban penggunaan sistem muncul, yaitu saat mereka memiliki tugas yang harus diselesaikan dengan menggunakan sistem. Perbedaan peran dalam pembagian tugas dan intensitas penggunaan dalam satuan kerja tempat mereka bekerja juga disinyalir dapat menyebabkan perbedaan intensitas penggunaan antara satu pengguna dengan pengguna lainnya.

Hasil ini mendukung hasil penelitian Budiyanto (2009) dan McGill, et al. (2003) yang menyatakan bahwa bahwa penggunaan sistem informasi pada konteks ini adalah penggunaan mandatory, sehingga tidak tepat dijadikan ukuran secara lebih tegas dengan ukuran-ukuran yang lain dalam variabel kesuksesan sistem informasi. Dalam penelitian McGill, et, al. (2003) dinyatakan bahwa penggunaan tidak memberikan pengaruh terhadap kinerja individu dikarenakan penggunaan yang lama pada SI bukan mengukur manfaat terhadap pemakaian itu, tetapi lebih karena tidak efektifnya SI sehingga menyebabkan pemakaian yang lama pada SI.

Hasil ini tidak mendukung hasil penelitian Mulyono (2008) yang, membuktikan terdapat pengaruh pengunaan terhadap dampak individu. Mulyono (2008) menyatakan bahwa semakin sering pengguna memakai sistem informasi, biasanya diikuti oleh semakin banyak tingkat pembelajaran (degree of learning) sistem informasi. Peningkatan derajat pembelajaran, merupakan salah satu indikator terdapat pengaruh keberadaan sistem terhadap kualitas pengguna (individual impact). Individual impact merupakan pengaruh dari keberadaan dan pemakaian SIA terhadap kinerja, pengambilan keputusan dan derajat pembelajaran individu dalam organisasi. Penerapan sistem informasi yang baru akan berdampak pada reaksi yang ditunjukkan oleh perilaku individu dalam organisasi. Reaksi itu dapat berupa munculnya motivasi baru untuk bersaing dan meningkatkan kinerja.Secara positif keberadaan SIA akan menjadi rangsangan (stimulus) dan tantangan bagi individu dalam organisasi untuk bekerja secara lebih baik, yang pada gilirannya berdampak pada kinerja organisasi.

\section{Pengaruh Kepuasan Pengguna (KP) Terhadap Manfaat Bersih (MB)}

Penerimaan hipotesis kesembilan (H9) tersebut mengindikasikan bahwa kepuasan pengguna yang diwujudkan dengan keyakinan akan kebermanfaatan yang ditimbulkan dari penggunaan komdanas akan memberikan dampak bagi individu (penggunanya) sesuai dengan teori DeLone dan McLean (2003), dimana semakin pengguna sistem informasi merasa bahwa mereka memperoleh kebermanfaatan (usefulness) dari penggunaan sistem, seperti kemudahan pemahaman dan sangat memadainya sistem untuk menyelesaikan pekerjaan mereka, maka manfaat yang dirasakan akan semakin besar.

Hasil ini sesuai dengan kondisi di lapangan dimana kepuasan pengguna komdanas adalah konstruk yang dominan dalam menjelaskan manfaatmanfaat bersih komdanas. Hasil ini mendukung basil penelitian Purwanto (2007) dan Mulyono (2008) bahwa memang terdapat pengaruh kepuasan pengguna terhadap manfaat yang didapatkan. Hasil ini tidak mendukung 
hasil penelitian Radityo dan Zulaikha (2007) yang, membuktikan tidak terdapat pengaruh kepuasan penguna terhadap manfaat yang dihasilkan bagi individu maupun organisasi.

\section{PENUTUP}

\section{Simpulan}

Hasil penelitian ini dapat disimpulkan sebagai berikut: (1) Dari 2 model penelitian yang diajukan, keduanya memberikan hasil yang tidak jauh berbeda, (2) Pengujian hipotesis menunjukkan, kualitas informasi dapat memberikan pengaruh yang negatif terhadap kepuasan pengguna, (3) Kualitas informasi memberikan hasil yang positif terhadap penggunaan, (4) Kualitas sistem terbukti secara empiris memberikan pengaruh positif signifikan terhadap kepuasan pengguna dan penggunaaan, (5) Pengujian hipotesis menunjukkan, kualitas pelayanan memberikan pengaruh yang positif signifikan terhadap kepuasan peengguna, akan tetapi memberikan pengaruh negatif signifikan terhadap penggunaan, (6) Antara kepuasan pengguna dan penggunaan terbukti secara empiris tidak mempengaruhi satu sama lain, (7) Kepuasan pengguna terbukti secara empiris memberikan pengaruh positif signifikan terhadap manfaat bersih, dan (8) Penggunaan (use) tidak terbukti memberikan pengaruh positif terhadap manfaat bersih.

\section{Keterbatasan Penelitian}

Penelitian ini memiliki beberapa keterbatasan antara lain (1)Penelitian ini merupakan studi kasus yang meneliti hanya pada 1 korwil, sehingga hasil penelitian tidak dapat digeneralisasi pada korwil lain yang sejenis, (2) Kuesioner yang belum komunikatif dari segi bahasa dan memerlukan perlu perbaikan untuk penelitian berikutnya, (3) Penelitian hanya menggunakan 1 model teori (DeLone dan McLean) untuk mengevaluasi kesuksesan sistem informasi akuntansi, dan (4) Teknik pengumpulan data melalui kuisioner dilakukan tanpa ada pendampingan dengan memberikan kepercayaan penuh kepada responden untuk mengisinya. Peneliti hanya memberikan penjelasan mengenai pertanyaan-pertanyaan dalam kuisioner serta cara pengisiannya. Hal semacam ini kemungkinan menyebabkan hasil yang bias terhadap tingkat kepercayaan pada responden yang mengisi kuisioner tersebut.

\section{Saran}

Dari 9 hipotesis yang diajukan, 6 terbukti secara empiris. Dengan demikian, secara umum model kesuksesan sistem informasi DeLone dan McLean merupakan kerangka yang dapat dijadikan untuk memberikan evaluasi atas implementasi sistem informasi akuntansi di lingkup peradilan. Variabel kualitas sistem dan kualitas pelayanan terbukti memberikan pengaruh signifikan baik terhadap kepuasan pengguna, sementara kualitas informasi belum memberikan dampak positif terhadap kepuasan pengguna. Dengan hasil tersebut korwil Pengadilan Tinggi Mataram perlu terus-menerus memberikan perbaikan terhadap kualitas informasi sehingga dapat berujung pada kepuasan pengguna yang secara empiris terbukti berpengaruh positif terhadap manfaat bersih bagi organisasi yakni peningkatan produktifitas dan efektifitas kinerja.

Untuk penelitian selanjutnya, dapat diberikan beberapa saran sebagai berikut: (1) Memperbanyak korwil yang diteliti agar hasilnya lebih representatif sehingga dapat menggeneralisir kondisi yang sebenarnya dilapangan, (2) Penggunaan bahasa yang lebih komunikatif dalam kuesioner untuk memudahkan responden memahami maksud pertanyaan, (3) Melibatkan teoriteori dan kerangka kerja selain model kesuksesan sistem informasi DeLone dan McLean untuk menghasilkan model evaluasi efektivitas sistem informasi akuntansi yang lebih komprehensif, misalnya model Unified Theory of Acceptance and Use of Technology (UTAUT), Balance Score Card (BSC) dan Cost-Benefit Analysis (CBA), dan (4) Untuk mendapatkan hasil yang terpercaya dalam pengambilan data dari responden, sebaiknya diberikan pendampingan pada waktu memberikan jawaban atas kuesioner penelitian. 


\section{DAFTAR PUSTAKA}

Agustiani, Nurul Huda. 2010. "Pengaruh Pemanfaatan Sistem Informasi Akademik Terpadu (SIKADU) Terhadap Kinerja Individual Dengan Kemudahan Penggunaan Sebagai Variabel Moderating (Studi Empiris pada Fakultas Teknik Universitas Negeri Semarang)". Tesis Program Pasca Sarjana, Fakultas Ekonomi Universitas Diponegoro, Semarang.

Bailey,J.E. dan S.W. Pearson, 1983. Development of a Tool for Measuring and Analyzing Computer User Satisfaction, Management Science 29 (May)

Bodnar, George H., Hopwood, William S, 2006. Sistem Informasi Akuntansi, Edisi 9, Yogyakarta : Andi.

Budiasih, 2002. "Dampak Perkembangan Teknologi Informasi Terhadap Sistem Informasi Akuntansi" Jurnal Ekonomi dan Bisnis, No.3, Jilid 7.

Budiyanto, 2009. "Evaluasi Kesuksesan Sistem Informasi Dengan Pendekatan Model DeLone Dan Mclean (Studi Kasus Implementasi Billing System Di RSUD Kabupaten Sragen)". Tesis Program Pasca Sarjana, Fakultas Ekonomi Universitas Sebelas Maret, Surakarta.

Burton-Jones, A. \& Straub, D. 2006. "Reconceptualizing system usage: an approach and empirical test". Information Systems Research, 17(3), pp. 220-246.

Caldeira M.M dan Ward J.M, 2003. "Using resource based theory to interpret the successful adoption and use of information systems and technology in manufacturing small and medium-sized enterprises". European Journal of information systems. 12(2): 127-141.

Chin, W.W. dan P.A. Todd, 1995. "On the Use, Usefulness, and Ease of Use of Structural Equation Modeling in MIS Research: A Note of Caution". MIS Quarterly, June, p. 237- 246

Davis, Fred D, 1989. "Perceived Usefulness, Perceived Ease of Use, and User Acceptance of Technology”. MIS Quarterly.
Davis, G.B, 1992. "Information Systems Conceptual Foundations: Looking Backward and Forward". University Of Minnesota, USA.

DeLone, W.H., dan McLean, E.R, 1992. Information Systems Success: The Quest for the Dependent Variable, Information Systems Research. 2003. "The DeLone and McLean Model of Information System Success: A ten-Year Update". Journal of Management Information Systems.

Ghozali, Imam, 2008. Structural Equation Modeling metode alternatif dengan Partial Least Square, edisi 2, Semarang : BPUndip.

Hansen, Don R. and Maryanne M. Mowen 2006. Managemen Accounting. $5^{\text {th }}$ edition.Cincinnati-Ohio: SouthWestern College Publishing.

Haryanta, 2008. "Pengaruh Penggunaan Sistem Informasi Perpustakaan (SIPUS) Terhadap Kinerja Pelayanan Sirkulasi di Perpustakaan Universitas Gadjah Mada Yogyakarta”. Skripsi Program Studi Ilmu Perpustakaan Kelas Khusus Jurusan Ilmu Perpustakaan dan Informasi Fakultas Adab UIN Sunan Kalijaga, Yogyakarta.

Iranto, Bondan Dwi, 2012. "Pengaruh Kepuasan Pengguna Sistem Informasi Terhadap Kinerja Individu (Studi pada PT.PLN (Persero) Distribusi Jawa Tengah dan DIY)". Skripsi Fakultas Ekonomika dan Bisnis, Universitas Diponegoro, Semarang.

Istianingsih dan Wijanto, Setyo Hari, 2008. Pengaruh Kualitas Sistem informasi, Kualitas Informasi, dan Percived Usefulness Terhadap Kepuasan Pengguna Software Akuntansi. Simposium Nasional Akuntansi IX, Pontianak.

Istianingsih dan Utami, Wiwik, 2009. Pengaruh Kepuasan Pengguna Sistem Informasi Terhadap Kinerja Individu (Studi Empiris Pada Pengguna Paket Program. Aplikasi Sistem Informasi Akuntansi Di Indonesia). Simposium Nasional Akuntansi XII, Palembang. 
Jogiyanto, 2007. Model Kesuksesan Sistem Teknologi Informasi, Yogyakarta: Andi.

2009. Konsep Dasar dan Komponen Sistem Informasi Berbasis Komputer Edisi 2. Yogyakarta : BPFE.

2011. Konsep dan Aplikasi Structural Equation Model, Yogyakarta: UPP STIM YKPN.

Komala, Adeh Ratna, 2012. "The Influence Of The Accounting Managers' Knowledge And The Top Managements' Support On The Accounting Information System And It's Impact On The Quality Of Accounting Information : A Case Of Zakat Institutions In Bandung”. Journal of Global Management, July 2012, Vol 1.

Latan, Hengky dan Imam Ghozali. 2012. Partial Least Square: Konsep, Teknik, dan Aplikasi SmartPLS 2.OM3. Semarang: Badan Penerbit Universitas Diponogero.

Latif, Abdul, 2010. “Analisis Keberhasilan Siskohat Kanwil Kementerian Agama". Tesis Program Pasca Sarjana, Fakultas Ekonomi Universitas Sebelas Maret, Surakarta.

Latifah, Lyna dan Sabeni, Arifin, 2007. faktor keperilakuan organisasi dalam implementasi sistem akuntansi keuangan daerah (studi empiris pada pemerintah kabupaten dan kota jawa tengah dan daerah Yogyakarta) Simposium Nasional Akuntansi X. Makassar.

Livari, Juhani. 2005. "An Empirical Test of the DeLone and McLean Model of Information System Success". Database for Advances in Information Systems, Spring, 36(2): pp 8-27.

Maharsi, Sri, 2000. "Pengaruh Perkembangan Teknologi Informasi Terhadap Bidang Akuntansi Manajemen". Jurnal Akuntansi \& Keuangan Vol. 2, No. 2, Nopember 2000, hal $127-137$.

Mahkamah Agung. 2011. Komdanas Pocketbook.

2014. Majalah Mahkamah Agung Edisi ke-6 Desember 2014.

Mardiasmo, 2004. Akuntansi Sektor Publik, Andi, Yogyakarta.
McGill, Tanya, Hobbs, Valerie, \& Klobas, Jane. 2003. "User-Developed Applications and Information Systems Success: a Test of DeLone and McLean's Model". Information resource Management Journal, 16(1): 24-45.

Mulyadi, 2001. Sistem Akuntansi, Yogyakarta: Salemba Empat.

Mulyono, Imam, 2009. "Uji Empiris Model Kesuksesan Sistem Informasi Keuangan Daerah (SIKD) Dalam Rangka Peningkatan Transparansi dan Akuntabilitas Keuangan Daerah". Tesis Program Pasca Sarjana Universitas Gajah Mada, Yogyakarta.

Myers, Barry L, Kappelman, Leon A. \& Prybutok, Victor.R. 2007. "A Comprehensive Model for Assessing the Quality of the Information System Function: Toward a Theory for Information System Assessment". Information Resource Management Journal, Winter, 10(1): 6-25.

Nugroho, Nurhasan, 2013. “Analisis Penerimaan Mahasiswa Baru (PMB) Online Universitas Kristen Duta Wacana Menggunakan Model Kesuksesan Sistem Informasi DeLone dan McLean (D\&M)". Skripsi Jurusan Akuntansi, Fakultas Ekonomi, STIE Bina Bangsa Banten, Banten.

Perdanawati, Luh Putu Vira. 2014. "Pengaruh Unsur-Unsur Kepuasan Pengguna Pada Efisiensi dan Efektivitas Kerja Pengguna Aplikasi Sistem Akuntansi Instansi di Satuan Kerja di Pendidikan Tinggi Provinsi Bali". Tesis Program Pasca Sarjana. Fakultas Ekonomi Universitas Udayana. Denpasar.

Petter, S., DeLone, W.H., McLean, E.R., 2008. "Measuring information systems success: models, dimensions, measures, and interrelationships". European Journal of Information Systems, 17, 236-263.

Pratiwi, Rika dan Cofriyanti, Ervi, 2013. "Analisis Penggunaan Sistem Aplikasi D-Pack Terhadap Kepuasan Pengguna Pada CV. Sumber Jadi Pangkal Pinang”. 
Skripsi Jurusan Sistem Informasi. STMIK GI MDP. Palembang.

Purwanto, Arie. 2007. "Rancangan dan Implementasi Model Pemeriksaan Kinerja Badan Pemeriksa Keuangan Republik Indonesia Atas Aplikasi E-Government di Pemerintah Daerah: Studi Kasus Kabupaten Sragen". Tesis Program Pasca Sarjana Universitas Gajah Mada. Yogyakarta.

Pusat Kajian dan Pengembangan Akuntansi, 2008. Modul Akuntansi Sektor Publik 2: Akuntansi Pemerintah Daerah, Mataram: PKPA, FE UNRAM.

Radityo, Dody dan Zulaikha, 2007. Pengujian Model DeLone and McLean Dalam Pengembangan Sistem Informasi Manajemen (Kajian Sebuah Kasus), Simposium Nasional Akuntansi X. Makasar.

Rai, A., Lang, S.S. dan Welker, R.B. 2002. "Assessing the Validity of IS Success Models: An Empirical Test and Theoretical Analysis". Information System Research, Vol.13 (1): 29-34.

Seddon.P.B. 1997. "A Respecification and Extension of The DeLone and McLean's Model of IS Success". Information System Research, 8: 240-250.

Sugiyono, 2013. Metodologi Penelitian Kuantitatif Kualitatif dan R\&D, Bandung: Alfabeta

Suryawan, Angellia Debora. 2013. "Analisis Kesuksesan Penerapan Sistem Informasi Pada Binus University Menggunakan Delone Mclean Information System Success Model dan Cobit Framework". Tesis Program Pasca Sarjana Universitas Bina Nusantara. Jakarta. .Undang-Undang Nomor 17 Tahun 2003 tentang Keuangan Negara

Tjakrawala dan Cahyo, 2010. Adaptasi Model DeLone dan McLean yang Dimodifikasi Guna Menguji Keberhasilan Implementasi Software akuntansi Bagi Individu pengguna : Studi Empiris Pada Perusahaan Dalam Industri Barang konsumsi yang Terdaftar di BEI, Simposium Nasional Akuntansi XIII. Purwokerto.
Triastoto, Bayu, 2015. "Dimensi Keberhasilan Penerapan Sistem Informasi Berdasarkan Model DeLone dan McLean". Tesis Program Studi Manajemen dan Bisnis, Institut Pertanian Bogor, Bogor.

Weber, Ron, 1999, Information System Control and Audit, First Edition, Upper Saddle River, New Jersey: Prentice Hall Inc.

Widodo, Handayani, Saifi, 2013. "Pengaruh Sistem Aplikasi Manajemen (SIM) Terhadap Kinerja Karyawan”. Jurnal Profit. Vol. 7, No. 1.

Zhu, K. \& Kraemer, K. L, 2005. "Postadoption variations in usage and value of e-business by organizations: cross-country evidence from the retail industry". Information Systems Research, 16(1), 61-84. 